11. McCormick J. The Global Environmental Movement. - London: Belhaven Press., 1989. - 259 p.

\section{References}

1. Blyumenberh $H$. Svit yak knyha / $H$. Blyumenberh, per. $\mathrm{z}$ nim., peredmova, komentari $\mathrm{V}$. Yermolenka. - K. : Libra, 2005. - 544 s.

2. Gardashuk T.V. Okhorona pryrody v Ukrayini yak skladova chastyna kulatury // Istoriya ukrayins?koyi kulatury $v$ 5-ty tomakh. - T.5: Ukrayins?ka kul ?tura XX - pochatku XXI stolit?. Knyha 4. - K.: Naukova dumka, 2013. - S.713 - 730.

3. Gor A. Zemlya u rivnovazi. Ekolohiya $i$ lyuds?kyy dukh / A. Hor; per. z anhl.; VHO "Ukrayina. Poryadok dennyy na KHKHI stolittya» ta Instytut staloho rozvytku. - K. : Intelsfera, 2001. - 404 s.

4. Yermolenko A. Sotsial ?na etyka ta ekolohiya. Hidnist? lyudyny - shanuvannya pryrody / A. M. Yermolenko. - K.: Libra, 2010. - 416 s.

5. Leopol'd O. Kalendar' peschanogo grafstva. M.: Mir, 1983. -248 s.

6. Teobal'd V. Ekologiya kak erzats-religiya i vopros yeye ratsional'noy obosnovyvayemosti // Voprosy filosofii. - 2003. - № 12. - S.93-99.

7. Shalahinov B. B. "Mahichnyy idealizm» Novalisa: sproba rekonstruktsiyi // Naukovi zapysky NaUKMA. - 2011. - Tom 124: Filolohichni nauky. - S. 77-88.
8. Shveytser A. Blagogoveniye pered zhizn'yu. M.: Progress, 1992. $-576 \mathrm{~s}$.

9. Fenomen sotsiopryrodnykh system. Svitohlyadno-metodolohichni narysy. - K.: Vydavets? PARAPAN, 2009. - $284 \mathrm{~s}$.

10. Bell M. An Invitation to Environmental Sociology. - California: Pine Forge Press, 1998. - 342 p.

11. Costain W.D., Lester J.H. The Evolution of Environmentalism // Environmental Politics and Policy: Theories and Evidence / Ed. By J.P.Lester. - Durham; London: Duke Univ.Press., 1995. - P.15-38.

12. Dalton R. The Green Rainbow: Environmental Groups in Western Europe. - New Hawen; London: Yale Univ.Press., 1994. - 305 p.

13. Diez-Hochleither R. Foreword // King A., Schneider B. The First Global Revolution: a Report by the Council of the Club of Rome. - N.Y.: Pantheon Book, 1991. - P.IX - XIV.

14. Environmentalism and British Romanticism. [Електронний

ресурс] - Адреса посилання: http://web.utk.edu/ gerard/romanticpolitics/ecology

15. Gottlieb R. Forcing the Spring: the Transformation of the American Environmental Movement. - Washington: Island Press, 1993. - 413 p.

16. McCormick J. The Global Environmental Movement. - London: Belhaven Press., 1989. - 259 p.

УдК 165.21(045)

\title{
Ірина Грабовська
}

\section{НЕОІМПЕРСЬКІСТЬ СУЧАСНОÏ РОСІЇ ЯК ІСТОРИЧНИЙ ВИКЛИК ДЛЯ УКРАЇНСЬКИХ ПОСТКОЛОНІАЛЬНИХ ЕЛІТ}

Анотація: У статті проводиться аналіз політики та практики неоімперіалізму РФ, досліджується специфріка путунізму як історичного виклику, що постав перед постсовєтськими постколоніальними елітами колишнього СССР, в даному випадку - перед українськими. Існуюча певна толерація щодо культури колонізатора, притаманна чималій кількості представників українських еліт, як політичних, так і економічних та творчих, є однією з ознак їхньої неподоланої постколоніальності, що, у свою чергу, заважає перетворенню України на сучасну європейську цивілізовану державу та повноцінну модерну націю. Потреба у більш рішучому протистоянні політичним та ідеологічним впливам сучасного Кремля, його неоімперським діям, надання ефрективнішого та жорсткішого опору агресорові - путінській Росії, що вторглася на територію України та нав'язала гібридну війну їі народові, $є$ не лише вимогою, актуальною для самозбереження та утвердження української самостійної нації, але і наполегливою порадою, яка виходить із вуст прихильних до України політиків різних держав та просунутих аналітиків із самої теперішньої Росії. Думку про те, що Україна повинна набагато рішучіше виступати проти політики та дій путінської Росії неодноразово висловлювала, наприклад, президент Литви Даля Грібаускайте. Здатність до ефективного протистояння підступному агресорові путінській Росії - стала сьогодні екзаменом для українських еліт щодо їхньої життєспроможності та ефрективності.

Ключові слова: еліти, українська держава, українська нація, путінізм, неоімперіалізм Росії, гібридна війна, історичний виклик.

\section{Irina Grabovska}

\section{THE NEO-IMPERIALISM OF MODERN RUSSIA AS A HISTORICAL CHALLENGE FOR UKRAINIAN POST-COLONIAL ELITS}

Abstract: The article analyzes the policy and practice of neo-imperialism in the Russian Federation, examines the specificity of Putinizm as a historical challenge posed by the post-Soviet post-colonial elites of the former USSR, in this case, the Ukrainian ones. Existing certain toleration of the culture of the colonizer, inherent in a large number of representatives of the Ukrainian elites, both political, and economic and creative, is one of the hallmarks of their unshakable post-colonialism, which, in turn, hinders the transformation of Ukraine into a modern European civilized state and a full-fledged modern nation. The need for a more determined opposition to the political and ideological influences of the modern Kremlin, its neo-imperial actions, the 
provision of more effective and tougher resistance to the aggressor-Putin's Russia, which invaded Ukraine and imposed a hybrid war on its people, is not only a requirement that is relevant to self-preservation and consolidation Ukrainian independent nation, but also a persistent advice from the politicians of different countries who are committed to Ukraine and advanced analysts from the present-day Russia. Moreover, the real history of post-Soviet Ukraine and the post-Soviet Russia is a confirmation of the differences, including ideological, between the two peoples. At a time when post-colonial Ukraine was looking for itself in the labyrinths of many, and especially of the two-vectored, having finally ended on the road to a common European home, Russia tried to become democratic, but its efforts in this direction ended in defeat. Some of the contemporary Russian philosophers generally argue that the post-Soviet period in Russia went on an effort to return to the USSR. The Russian post-Soviet postcolonial period tried to get rid of their own "humiliation" and "to rise from their knees". A number of contemporary Russian intellectuals even argues that raising the people from their knees is the only real merit of the President of the Russian Federation VV. Putin before the Russian people. For example, the president of Lithuania Dalia Grybauskaite has repeatedly expressed the opinion that Ukraine should take a much more resolute stand against the policies and actions of Putin's Russia. The ability to effectively confront an insidious aggressor - Putin's Russia - has become an exam today for Ukrainian elites regarding their viability and effectiveness.

Key words: elite, Ukrainian state, Ukrainian nation, Putinizm, neo-imperialism of Russia, hybrid war, historical challenge

Постановка проблеми. Проблема становлення нової української еліти, здатної до ефективного націє- та державотвотворення, залишається чи не найгострішою протягом усіх років існування незалежної України. У теоретичному доробку українських (і не лише) науковців ця проблематика залишається серед найактуальнішої всі роки української самостійності. Роботи, присвячені вказаному питанню, складають на теперішній час не лише томи наукових праць, а навіть цілі бібліотеки. Проте, утвердження путінізму як новітньої ідеології, політики та практики на теренах сучасної РФ, гібридна війна Росії проти України породжує нові гострі виклики, що постають перед діючими елітами української держави, і не лише політичними. Зрештою, здатність до відпорності неоімперським впливам та державотворча спроможність наших еліт $€$ однією з найголовніших умов національної безпеки країни, підставою її життєспроможності.

Не секрет, що ще і до цього часу українські еліти залишаються багато в чому постколоніальними. Попри розв'язану Росією гібридну війну проти України ще і до теперішнього часу частина представників українського громадянства, серед яких $€$ чимало інтелектуалів, продовжують стверджувати, що російська культура за внутрішньою суттю залишається гуманістичною. Аналізуючи таку реальність, політолог С. Грабовський пише: «Досі й у світі, й в Україні вистачає людей (зокрема й таких, які вважають себе високоосвіченими), які переконані: як Сталін та сталінізм, так і Путін та путінізм з їхніми імперіалістичними мареннями і діями $€$ якимись абераціями великої російської культури. Мейнстрім же цієї культури зовсім інший, це високий гуманізм і вселюдська чуйність. I досить усунути диктатора, щоб усе повернулося на круги свої й російський імперіалізм припинив існування» [4].

Однією 3 ознак постколоніальності еліт $\epsilon$ прихована чи явна толерація культури колонізатора, нездатність розгледіти її імперську ментальну основу. А між тим «...імперіалізм - не щось зовнішнє, а іманентна складова мейнстріму російської культури, самої її серцевини. Він нерідко забарвлює у вельми специфічні кольори, безумовно, присутні в ній гуманізм і здатність абсорбувати досягнення інших культур, вміння генерувати нові для світу ідеї та вміння відгукуватися на чужий біль. Не забуваймо, скажімо, що новою (і випробуваною на практиці!) ідеєю, запропонованою століття тому Росією світові, став тоталітаризм, а відповіддю на чужий біль стали у $1960-1980-x$ роках закордонні походи «воїнів-інтернаціоналістів». А досягнення чужих культур абсорбувалися російською передусім у тій частині, що стосувалася нових військових розробок і військового ж мистецтва...» [4].

Саме постколоніальність бізнесових, політичних, творчих еліт призводить до ситуації, що загрожує не лише у військовому плані, а й у ідеологічному та світоглядному процесові українського націє- та державотворення. Та й політика путінізму, яка має чітко визначені ідейні, ідеологічні, світоглядні орієнтири (всі вони $є$ проімперськими) становить новий історичний небезпечний виклик для українських еліт в цілому.

Частина українських еліт, як і значна частина західних інтелектуалів, стверджує Е. Блан, продовжують дивитись на путінську Росію крізь "рожеві окуляри" [1].

Аналіз досліджень і публікацій. Зазначена у статті тема, хоча і активно розробляється в межах соціогуманітарних досліджень в сучасній Україні, ще не набула широкого теоретичного представлення у наукових працях українських дослідників. У аналітичній доповіді «Концептуальні засади розвитку системи забезпечення національної безпеки» (2015 р.) вказується на «реальне підвищення рівня загроз національним інтересам і життєдіяльності кожної людини, обумовлене низкою нових проблем, з якими стикається суспільство...». Така ситуація потребує «...формування чіткого механізму прийняття узгоджених рішень та швидких, скоординованих дій», адже «у кризові періоди розвитку держави, коли протиріччя в різних сорерах загострюються, ... держава і суспільство мають здійснювати упереджувальні заходи, які мінімізували б негативні наслідки загроз...» [8, с. 3].

Різнорівневість та різноплановість загроз, що виникають перед сучасною Україною, насамперед, з боку Росії, вимагають не лише їхньої вчасної та адекватної оцінки, але й рішучих та ефективних дій спротиву. Насамперед, відповідальність за розгортання певної реальної ситуації в країні (як 
позитивної, так і негативної) покладається на діючі еліти. Аналізуючи культурну політику сучасної Росії у відношенні до України, директор Інституту стратегічних досліджень В. Горбулін стверджує: «Російська культурна політика на українському напрямі була повністю інтегрована в загальну стратегію ліквідації української державності. Для ведення російської пропаганди широко використовуються не тільки 3Мl, але й культурнорозважальна індустрія. Російська культурна експансія проти України здійснювалась свідомо і наполегливо протягом усіх років незалежності, чому сприяла неефективність державної гуманітарної i культурної політики». Горбулін докладно проаналізував, як Росія роками готувалася до агресії проти України. Навіть масова культура - елемент війни [3].

Дослідник М. Дроботенко вказує на те, що «...теорія хаосу і розвалу, дезінтеграції будь-яких об'єднань, ставлення до колишніх республік СРСР як до колоній покладено в основу існування й діяльності сьогоднішньої Росії» [6, с. 31].

Серед авторських робіт аналіз даної проблеми заторкується у низці статей [5].

Мета дослідження. У даній статті пропонується певний аналіз неоімперськості сучасної Росії та ідейних засад путінізму в контексті здатності до відпорності щодо ворожих впливів сучасних українських еліт.

\section{Виклад основного матеріалу.}

Путінізм як ідеологічний, ширше - теоретичний конструкт базується на неоімперській доктрині сучасного Кремля, з такими крайніми проявами, якими $€$ рашистські теорії. В структурі цього світогляду переважають відтворені консервативні та радикальні ідеї, що беруть свій початок як із XУIII - XIX ст.ст., так і з совєтського та постсовєтського періоду. Проте, коли мова заходить про Україну та її місце в структурі новітнього російського імперіалізму, навіть ліберально налаштовані представники сучасних російських еліт не можуть уникнути експансіоністських, загарбницьких настроїв. Так, наприклад, курс росієвєдєнія, який викладається в сучасних російських школах та вишах, розпочинає історію Росії з Київської Русі. Його натхненник i промоутер Ігор Чубайс навіть запропонував для уникнення конфрлікту між «народами-братьями» перенести столицю майбутньої спільної відновленої держави з Москви до Києва. Проте, останні роки роздільного історичного існування у межах незалежних держав значно розвели насправді начебто існуючу спільність - «єдіний совєтскій народ».

А між тим, чимало сучасних російських дослідників дотримуються думки, що Україна була саме колонією Росії, а не повноправним членом багатонаціональної держави. Наприклад, О. Широпаєв пише: «Украина стала славянской колонией Российской империи. Я сформулирую даже более определенно: Русь стала колонией Орды. Причем особый гротеск данной ситуации в том, что метрополия называет себя Русью, в то время как собственно Русь лишена этого имени. Колонизаторы назвали Русь-Украину Малороссией, тем самым желая подчеркнуть ее подчиненное положение по отношению к Великороссии. На протяжении двух веков империя рассматривала украинцев лишь как одну из компонент «триединого русского народа» (был создан такой имперско-пропагандистский конструкт для оправдания «московизации» украинцев и белорусов). Тот факт, что украинцы и русские (в смысле - великороссы) - два разных народа всячески игнорировался» [12].

Принципову відмінність українців від росіян підкреслюють не лише українські вчені, а й самі дослідники 3 РФ. «Устойчивость украинского самосознания удивительна. На первом же крутом историческом повороте - в 1917 году - украинцы заявили: мы - другие. Причем, подчеркиваю, речь не о верхушечном, интеллигентском поветрии, а о глубинном движении, на что указывает массовая поддержка того же Петлюры со стороны украинского крестьянства. Победившие большевики не могли не считаться с этим фактом, и в результате украинцы были признаны особым народом со своей, пусть и декоративно-колониальной, но, все же, республикой. Тем не менее, потребовался Голодомор, чтобы снять угрозу украинского народного восстания и выхода Украины из состава СССР. В период Второй мировой войны украинским патриотам пришлось вести войну на два фронта, поскольку не только Сталин, но и Гитлер рассматривали Украину только в качестве своей колонии. Пропагандистские утверждения о каком-то «пронацистском» характере украинского национально-освободительного движения звучат просто дико» [12].

Реальна історія постсовєтської України та постсовєтської РФ теж є підтвердженням відмінності, в тому числі і світоглядної, між двома народами. У той час, коли постколоніальна Україна шукала себе у лабіринтах багато- та особливо двовекторності, вийшовши зрештою на дорогу до спільного європейського дому, Росія спробувала стати демократичною, проте її зусилля у цьому напрямку завершились поразкою. Деякі із сучасних російських філософрів взагалі стверджують, що постсовєтський період у РФ пішов на зусилля повернутися до СССР. Росіяни увесь постсовєтський постколоніальний період намагались позбутися власного «приниження» і «піднятися 3 колін». Ряд сучасних російських інтелектуалів навіть стверджує, що піднімання народу з колін - єдина реальна заслуга президента РФ В.В. Путіна перед російським народом. А.Е. Разумов зазначає: «Сегодня мы ждем, чем окончится правление весьма популярного В народе президента В.В. Путина... Правление нынешнего президента во многих смыслах является весьма проблемным, но при нем население страны стало вновь обретать чувство собственного достоинства. Думаю, что это главный итог его работы и его вклад в национальную идею и национальный интерес России» [11, с. 14]. 
Загрозу путінської ідеології та базованого на ній світогляду не лише для сусідніх країн, але й для самої Росії розуміють тверезо мислячі російські інтелектуали. Так, представник правозахисної організації РФ О. Широпаєв абсолютно справедливо стверджує, що ненависть путінської Росії до України $€$ ненавистю до неї як принципово іншого начала істинної Русі. «Ненавидя Украину, путинская Россия ненавидит Русь как некое культурно-политическое начало. В ненависти к украинской революции проявилась русофобская сущность России как Орды. Россия-Орда исторически сформировала своих «русских» - послушных и неприхотливых рабов. Их сознание извращено настолько, что они не узнают в Украине, в Майдане Русь. Зато узнают «Русь» в Сталине, в Иване Грозном, в Путине - чуть ли не в Пол Поте. А в собственно Руси они видят «бендеровщину» и «нацизм»» [12].

3 викладеними вище думками автора важко не погодитись. О. Широпаєв стверджує, що росіяни прийняли і змирились зі своєю «ординською долею», опоетизувавши ії. Власну традиційну відсталість та агресивні устремління вони виправдовують месійністю власної долі, побудувавши цілу історіософрію російської ординської специфіки. «Украинцы же боролись и продолжают бороться за изначальную, европейскую, именно русскую судьбу. Они, по сути своей, более русские, чем мы. Мы Орда и хотим оставаться ею. Более того, мы хотим и Украину включить в свой ордынский мир, называя его «русским». Мы кричим украинцам о «братстве», а на деле хотим навязать им курс ускоренной евразийской мутации. А Украина не желает быть частью Орды. Украина не желает и зависать между Ордой и Европой. Украина желает быть частью Европы. Русью» [12].

Цю історичну, політичну. ментальну, світоглядну тощо відмінність, як вказують чимало інтелектуалів Заходу, деякі антипутінські аналітики з РФ та ряд українських серйозних аналітиків, сучасним діючим в Україні елітам потрібно значно рішучіше та ефективніше використовувати в утвердженні як самої країни на міжнародній арені, так і у боротьбі із ворожим путінським режимом. Як зазначає відомий російський політолог А. Піонтковський, Україна повинна припинити «бавитись» у Мінські домовленості і рішучіше проводити антипутінську політику. Для цього є сьогодні сприятливі зовнішні умови. За словами А. Піонтковського, американський військово-політичний істеблішмент "ізолював" президента США Дональда Трампа і держсекретаря Рекса Тіллерсона, які мають пропутінські симпатії, відкривши Україні шлях до ефективнішої антипутінської політики. "Волкер у своїх заявах відображає одностайну думку Конгресу США і американського військово-політичного істеблішменту, які фрактично ізолювали путінську агентуру у себе в країні. Я кажу про Трампа і Тіллерсона. Така позиція США дуже сприятлива для України. Українській владі час наблизитися до тієї тональності і формулювань, які використовує Волкер. Сподіваюся, незабаром Верховна Рада ухвалить закон про окуповані території, де зрештою назве речі своїми іменами. А саме, що на Донбасі триває війна між Україною і РФ, і відповідальність за окуповані території несе країнаагресор. Це позиція Волкера і США. Добре, якби така сама позиція була б і в самої України", - підкреслює А. Піонтковський [9].

Називаючи сучасну російську державу фашистською (Андрей Пионтковский: «Россия мутантное, фашистское государство»), аналітик означує її політику щодо України влучною фразою «братское изнасилование». Щоб припинити ці дії путінського режиму, А. Піонтковський пропонує українській політичній еліті наступне: «Сейчас усилия украинской дипломатии должны быть сосредоточены на том, чтобы мировое сообщество обеспечило разделение сторон, прекращение огня и в юридическом плане зафиксировало, что это агрессия, что это временно оккупированные территории и что они должны быть возвращены Украине. Они и будут возвращены после падения путинского режима» [10].

Експерт вважає, що позиція американської політичної еліти щодо війни РФ проти України буде однозначною та рішуче спрямованою проти дій В.В. Путіна. «Які рішення можуть знайти з Москвою? Тут тільки один варіант, виходячи із заяв Волкера: російські війська покидають територію України, а Київ повертає собі контроль над усім українським кордоном. Поки Путін... сидить у Кремлі, Росія на це не піде. Волкер не шукає компромісів з окупаційним режимом» [9], - стверджує А. Піонтковський.

Зрештою, у ЗМІ активно обговорюється інформація щодо ніби-то наданих американцями 180 днів російським бізнес-елітам для усунення Путіна та його оточення від влади в Росії [9].

Аналізуючи цю інформацію, чимало експертів зазначають, що і В.В. Путін, знаючи про існуючі реалії, буде робити все для того, щоб утриматись при владі. I це ситуація надзвичайно загрозлива для України. «Путіну потрібна підтримка не народу, а свого оточення. У Росії свита грає короля, і свита розуміє: санкцій не знімуть, поки Путін при владі. Намагаючись переконати близьке оточення, що без нього ніяк, президент РФ буде по максимуму нагнітати обстановку всередині Росії і за її межами, особливо в Україні, - заявив екс-розваідник Копка. Еліта РФ усе частіше запитує: "Вовка знову кудись полізе з "Буками", нарветься на санкції, а з нашими капіталами що буде?"» [7].

Думку про те, що Україна повинна рішучіше виступати проти політики путінської Росії неодноразово висловлювала і президент Литви Даля Грібаускайте. Так, в одному з останніх інтерв'ю вона заявила, що у Литві «...ніхто більше не слухає російські ультиматуми» [2], тим самим пропонуючи і українським політичним елітам перейти до такого стилю спілкування з агресором. I 3 цією думкою важко не погодитись. 
Висновки: Таким чином, путінізм $€$ на сьогодні серйозним історичним викликом для українських еліт, екзаменом щодо їхньої державо- та націє-творчої спроможності, здатності перейти від пост колоніальної якості до повноцінної суб'єктності.

1. Блан Е. Родом із КГБ. Система Путіна / Елен Блан. - К.: Темпора, 2009. - 360 с.

2. Грібаускайте: ніхто більше і не слухає російські ультиматуми. - [Електронний ресурс] // Режим доступу: http://uzv.org.ua/2017/09/04/gribauskaytenihto-bilshe-i-ne-sluhaye-rosiyski-ultimatumi/

3. Горбулін докладно проаналізував, як Росія роками готувалася до агресії проти України. Навіть масова культура - елемент війни. - [Електронний ресурс] // Режим доступу:

http://texty.org.ua/pg/news/textynewseditor/read/655 83/Gorbulin_dokladno_proanalizuvav_jak_Rosija_rokam y_gotuvalasa

4. Грабовський С. На що і на кого спирається Путін? Безмежжя культурно-політичних обширів російського імперіалізму / Сергій Грабовський. [Електронний ресурс] // Режим доступу: https://day.kyiv.ua/uk/article/kultura/na-shcho-i-na-kogospyrayetsya-putin

5. Див.: Грабовська І.М. Російський колоніалізм і сучасна Україна: теорія та практика / І.М. Грабовська // Zwiastowac. Nauki i praktyki. Priorytetowe obszary badawcze: od teorii do praktyki. - Lublin, 2016. - C. 58 - 61; Грабовська І.М., Щербак Н.О. Сучасний кремлівський імперський месіанізм - загроза національно-державницькій ідентифікації громадян України / І.М. Грабовська, Н.О. Щербак // Versus. - № 8. - 2016. - С. 57 - 60; Грабовська І.М. Зміна концептів на пострадянському просторі як відображення реалій сьогодення / I.M. Граборвська // Zwiastowac. Nauki i praktyki. Badania podstawowe i stosowane: wyzwania i wyniki. - 30.08.2016 - 31.08.2016. -Zakopane - p. 45 49; Грабовська Ірина. Актуальність дослідження консолідації українства в постколоніальну добу / Ірина Грабовська // Українознавчий альманах. Вип.19. - К.: «Міленіум+», 2016. - С. 9 - 13; Грабовська Ірина. Філософрські витоки та сенс путінізму / Ірина Грабовська // Вісник КНУТШ «Українознавство». - 1(18)/2016. - С. 13 - 17; Грабовская И.Н., Талько Т.Н. «Русская идея» и философско-религиозные поиски В. Розанова в контексте современности / И.М. Грабовская, Т.Н. Талько // Философія і політологія в контексті сучасної культури. Науковий журнал. Вип.1(10). Дніпропетровськ, 2016. - С. 49 - 54.

6. Дроботенко М. Постколоніальний вплив на політичні реалії сучасної України / Микола Дроботенко. - Українознавчий альманах. - Вип. 20. К.: «Міленіум+», 2017. - С. 31 - 34.

7. Екс-розвідник Копка: Еліта РФ усе частіше запитує: "Вовка знову кудись полізе з "Буками", нарветься на санкції, а 3 нашими капіталами що буде?" - [Електронний ресурс]. // Режим доступу: http://gordonua.com/ukr/news/politics/eks-rozvidnikkopka-elita-rf-vse-chastishe-zapituje-vovka-znovu-kudispolize-z-bukami-narvetsja-na-sanktsiji-a-z-nashimikapitalami-shcho-bude-191027.html
8. Концептуальні засади розвитку системи забезпечення національної безпеки України : аналіт. доп. / О. О. Резнікова, В. Ю. Цюкало, В. О. Паливода, С. В. Дрьомов, С. В. Сьомін. - К. : НІСД, 2015. - 58 с.

9. Піонтковський Андрій. Російській еліті дали 180 днів на повалення Путіна (інтерв'ю). - [Електронний ресурс] // Режим доступу: http://expres.ua/news/2017/08/31/259968-rosiyskiy-elitidaly-180-dniv-povalennya-putina-ekspert

10. Пионтковский А. Сколько можно играть в Минские соглашения? /

Андрей Пионтковский. - [Электронный ресурс] // Режим https://www.obozrevatel.com/blogs/30762-skolkomozhno-igrat-v-minskie-soglasheniya.htm

11. Разумов А.Е. Национальная идея и национальные интересы в России. Связь и разрыв поколений / А.Е. Разумов. - Философские науки. 4/2015. - С. 7 - 20.

12. Широпаев А. Цивилизационный водораздел человечества: Майдан или Орда / Алексей Широпаев. - [Электронный ресурс] // Режим доступа: euromaidanonline.comhttp://novaukraina.org/news/urn:n ews:14C0B6A

\section{References}

1. Blan E., 2009. Rodom iz K·HB. Systema Putina. [Originally from the KGB. Putin's system]. K.: Tempora, 360 (in Ukr).

2. Hribauskayte: nikhto bil'she i ne slukhaye rosiys'ki ul'tymatumy [Hribauskayte: no one else is listening to Russian ultimatums]. Retrieved from URL (in Ukr).

3. Horbulin dokladno proanalizuvav, yak Rosiya rokamy hotuvalasya do ahresiyi proty Ukrayiny. Navit' masova kul'tura - element viyny. [Gorbulin analyzed in detail how Russia was preparing for aggression against Ukraine for years. Even mass culture is an element of war]. Article. Retrieved from URL (in Ukr).

4. Hrabovs'kyy S. Na shcho i na koho spyrayet'sya Putin? Bezmezhzhya kul'turno-politychnykh obshyriv rosiys'koho imperializmu. [What and on whom Putin relies on? The boundless cultural and political circles of Russian imperialism]. Article. Retrieved from URL (in Ukr).

5. Dyv.: Hrabovs'ka I.M. 2016. Rosiys'kyy kolonializm i suchasna Ukrayina: teoriya ta praktyka. [Russian colonialism and modern Ukraine: theory and practice]. Article. Zwiastowac. Nauki i praktyki. Priorytetowe obszary badawcze: od teorii do praktyki. Lublin, C. 58 61 (in Ukrain) ; Hrabovs'ka I.M., Shcherbak N.O. 2016. Suchasnyy kremlivs'kyy impers'kyy mesianizm zahroza natsional'no-derzhavnyts'kiy identyfikatsiyi hromadyan Ukrainy [Modern Kremlin imperial messianism - a threat to the national-state identity of Ukrainian citizens]. Article. Versus, \# 8, S. 57 - 60; Hrabovs'ka I.M. 2016. Zmina kontseptiv na postradyans'komu prostori yak vidobrazhennya realiy s'ohodennya [Change of concepts in the post-Soviet space as a reflection of the realities of the present]. Article. Zwiastowac. Nauki i praktyki. Badania podstawowe i stosowane: wyzwania i wyniki. Zakopane, p. 45 - 49 (in Ukr); Hrabovs'ka I. 2016. Aktual'nist' doslidzhennya konsolidatsiyi ukrayinstva $\mathrm{v}$ 
postkolonial'nu dobu [The urgency of the study of the consolidation of Ukrainians in the post-colonial era]. Article. Ukrayinoznavchyy al'manakh. Vyp.19. K., «Milenium+», S. 9 - 13 (In Ukr); Hrabovs'ka Iryna. 2016. Filosofs'ki vytoky ta sens putinizmu [Filosofs'ki vytoky ta sens putinizmu]. Article. Visnyk KNUTSh «Ukrayinoznavstvo». 1(18), s. 13 - 17 (in Ukr); Hrabovskaya Y.N., Tal'ko T.N. 2016. «Russkaya ydeya» y fylosofsko-relyhyoznde poysky $V$. Rozanova $v$ kontekste sovremennosty ["The Russian Idea" and the philosophical and religious search for $\mathrm{V}$. Rozanov in the context of modernity]. Article. Fylosofiya i politolohiya $v$ konteksti suchasnoyi kul'tury. Naukovyy zhurnal. Vyp.1(10), Dnipropetrovs'k, s. 49 - 54 (in Ukr).

6. Drobotenko M. 2017. Postkolonial'nyy vplyv na politychni realiyi suchasnoyi Ukrayiny. [Postcolonial influence on the political realities of modern Ukraine]. Ukrayinoznavchyy al'manakh. Vyp. 20, K.: «Milenium+», s. $31-34$ (in Ukr).

7. Eks-rozvidnyk Kopka: Elita RF use chastishe zapytuye: "Vovka znovu kudys' polize z "Bukamy", narvet'sya na sanktsiyi, a z nashymy kapitalamy shcho bude?" [Ex-spy Copka: Elita RF increasingly asks: "The wolf again will climb somewhere with" Bukami ", will

from URL (in Ukr). break into sanctions, and what will happen to our capital?"]. Article. Retrieved from URL (in Ukr).

8. 2015. Kontseptual'ni zasady rozvytku systemy zabezpechennya natsional'noyi bezpeky Ukrayiny : analit. dop. / O. O. Reznikova, V. Yu. Tsyukalo, V. O. Palyvoda, S. V. Dr'omov, S. V. S'omin. [Conceptual framework for the development of the system for ensuring Ukraine's national security: analyst. add]. K., NISD, 58 (in Ukr).

9. Piontkovs'kyy Andriy. Rosiys'kiy eliti daly 180 dniv na povalennya Putina (interv"yu). [The Russian elite gave 180 days to overthrow Putin]. Article. Retrieved from URL (in Ukr).

10. Pyontkovskyy A. Skol'ko mozhno yhrat' v Mynskye sohlashenyya? [How much can you play in Minsk agreements?]. Article. Retrieved from URL (in Ukr).

11. Razumov A.E.2015. Natsyonal'naya ydeya y natsyonal'nыe ynteresы v Rossyy. Svyaz' y razrblv pokolenyy. [National idea and national interests in Russia. Communication and Generational Breakdown]. Article. Fylosofskye nauky, 4, s. 7 - 20 (in Ukr).

12. Shiropaev A. Civilizacionnyj vodorazdel chelovechestva: Majdan ili Orda [Civilizational divide of humanity: Maidan or the Horde]. Article. Retrieved

Удк $94(477)+(=161.2)$

\section{Сергій Грабовський}

\section{АНТИКОЛОНІАЛЬНИЙ ДИСКУРС УКРАЇНСЬКИХ МИСЛИТЕЛІВ КІНЦЯ ХІХ - ПЕРШОÏ ТРЕТИНИ ХХ СТОЛІТТЯ}

Анотація: Стаття присвячена аналізу чільних ідей антиколоніального дискурсу українських мислителів доби становлення модерної нації. У центрі уваги - погляди Юліана Бачинського, Івана Франка, Лесі Українки, Сергія Мазлаха та Василя Шахрая, Михайла Волобуєва. Автор ставить на меті змістовну денонсацію тих концептуальних засад мейнстріму сучасних західних постколоніальних студій, які ототожнюють колонії та колоніалізм із гнобленням європейцями інших народів за расовими чинниками або/та з експлуатацією «заморських територій», тобто країн в інших частинах світу. На думку автора, такі підходи засвідчують істотну деградацію світової соціально-теоретичної думки у порівнянні з її здобутками 100-150-річної давнини, коли в число колоній включалися $і$ «колонії європейського типу», які виступали об'єктами експлуатації Російської та Германської імперій. Ба більше: колонії Російської імперії «класичного типу», тобто розташовані в Азії і грунтовані на расовому принципі, також здебільшого перебувають поза полем зору сучасних постколоніальних студій. А тим часом ідеться про нинішні постколоніальні держави Центральної Азії. Відтак виглядає не лише доцільним, а й необхідним звернення до напівзабутої спадщини українських мислителів, що зверталися до антиколоніального дискурсу. Стаття окреслює їхні специфічні підходи до колоніальної проблематики, антиколоніальної боротьби та постколоніального націєтворення. Особлива увага присвячена у статті ідеям Михайла Волобуєва, в яких поєднані економічні, політичні, соціально-культурні й екзистенційні чинники.

Ключові слова: постколоніальні студії, колонія європейського типу, російський імперіалізм, антиколоніальний, український націонал-комунізм

\section{Serhiy Hrabovsky}

\section{ANTY-COLONIAL DISCOURCE OF UKRAINIAN THINKERS OF THE LATE 19th AND THE FIRST THIRD OF 20th CENTURY}

Abstract. The problems of colonialism and post-colonialism are very important for the modern world. Postcolonial studios are one of the key components of intellectual discourse. However, most of them have a serious flaw, namely the reduction of the topic to the collapse of colonial expansion and colonial exploitation to racial and geographical factors. These studios are about as colonizers view Europeans, and as oppressed peoples of the colonies view residents of other parts of the world. These researchers also do not pay attention to the fact that the Russian Empire had a colony at one time, not in America or Africa, but most of its colonies were in Asia. In addition, the Russian Empire had colonies in Europe: Finland, part of Poland, most of Ukraine, and so on. In turn, the German empire held in colonial condition the part of Poland that belonged to it. In Europe, there 